\title{
Application of Multi-Criteria AHP and TOPSIS Methods to Assess Sustainable Development of Poviat's in West Pomeranian Voivodeship (Poland) In 2017
}

\author{
Hab. Prof. US Adam Stecyk \\ Faculty of Management and Economics of Services, University of Szczecin \\ adam.stecyk@wzieu.pl
}

\begin{abstract}
The aim of the article is to present the practical use of a combination of two multi-criteria methods: FAHP fuzzy analytic hierarchy process and TOPSIS methods for linear ordering of multi-feature facilities, in order to expertly assess the level of sustainable, socio-economic development of the West Pomeranian Voivodeship in 2017. The article has been divided into two main parts. The theoretical (methodological) part contains the characteristics of FAHP and FTOPSIS methods; in the empirical part, however, the results of the analysis were presented. The main source of statistical data is the annual report published by Statistical Office in West Pomeranian, which contains information on most important development areas (e.g. population, education and health, employment, macroeconomics, transport, tourism, agriculture, etc.). The proposed research concept can be used to build the computational models and indicators in order to look for more complex dependencies among factors which determine sustainable development of studied phenomena and objects.
\end{abstract}

Keywords: FAHP fuzzy, TOPSIS, method, sustainable development

\begin{abstract}
Introduction
In the conditions of a dynamically changing environment, management requires making rational decisions based on an optimal choice among available alternatives that meet a set of specific goals. The principle of sustainable development assumes that decision-making will be preceded by an analysis taking into account all aspects related to the process, in particular the problem of balancing social, economic and environmental criteria that determine the effects of the actions taken. In conditions of limited financial resources, decision problems are often limited to one criterion, most often price, which allows for a quick but not always right decision (Witkowska, 1996). Such a single criterion is not fully credible, acceptable and exhaustible, i.e. it has no property that a cohesive family of criteria should have (Roy, 1990). One of the proposals enabling creation, justification and transformation our preferences into a specific choice, taking into account the complexity of the analyzed activity or object is the application of the multi-criteria decision making methods (MCDM) ), (Boutkhoum, Hanine, Agouti, \& Tikniouine, 2017) (Trzaskalik, 2014), (Saaty, 2002), (Triantaphyllou, 2000), (Roy, 1990).

Multi-criteria decision-making methods allow selection of the variant best suited to specific goals and preferences (selection problem) and ranking of the considered decision-making alternatives from the best to the worst (problem of ranking). In other words, the MCDM methods focus on decision problems in which the set of all acceptable decisions is a discrete, containing a finite, predetermined number of possible variants of the solution (Bewszko, 2004). The most well-known multi-criteria methods include:
\end{abstract}

- ELECTRE (Elimination et Choice Translating Reality) I, II, III, IV (Banayoun, Roy, \& Sussman, 1966);

- SMART and SMARTER (Simple Multi-Attribute Ranking Technique and Simple Multi-Attribute Ranking Technique Exploiting Ranks) (Edwards \& Barron, 1994);

- $\quad$ MACBETH (Measuring Attractiveness by a Categorical Based Evaluation TecHnique) (Bana e Costa \& Vansnick, 1999);

- PROMETHEE I, II, MAPPACC, PRAGMA (Diech, Korbicz, Rutkowski, \& Tadeusiewicz, 2000);

- DEA (data envelopment analysis) (Charnes, Cooper, \& Rhodes, 1978);

- TOPIS (The Technique for Order of Preference by Similarity to Ideal Solution) (Boutkhoum, Hanine, Agouti, \& Tikniouine, 2017), (Jahanshahloo, Hosseinzadeh Lotfi i Izadikhah, 1999);

- $\quad$ AHP/FAHP (Fuzzy/Analytic Hierarchy Process) and ANP (Analytic Network Process) (Saaty, 2002).

The aim of the article is to present the practical use of a combination of two multi-criteria methods: FAHP fuzzy analytic hierarchy process and TOPIS methods for linear ordering of multi-feature facilities, in order to expertly assess the level of sustainable, socio-economic development of the West Pomeranian Voivodeship in 2017. The article has been divided into two main parts. The theoretical (methodological) part contains the characteristics of FAHP and FTOPSIS methods; in the empirical part, however, the results of the analysis were presented

Characteristics of Multi-Criteria Fahp and Topsis Methods

The multi-criteria AHP method was developed in the 1970s and has so far found application in many areas of socio-economic life,

\footnotetext{
${ }^{1}$ The administrative division of Poland covers three levels: voivodships, poviats and communes
}

The current issue and full text archive of this journal is available at

www.jraspublications.org/index.php/JRAS/issue/archive

Journal of Research in Administrative Sciences (JRAS)

VIII(I), 1-6, ISSN: 2664-2433 


\section{Hab. Prof. US Adam Stecyk}

such as: economy and spatial planning, ecology, transport and logistics, economics, management, politics, education, medicine, technology, etc. The basic assumption of the AHP method indicates the possibility of decomposing the decision problem into the hierarchical structure and the selection of the optimal variant in given conditions, according to the adopted criteria. The analysis is carried out using a relative scale of ratings / priorities based on reversible pairwise comparisons for both countable and uncountable criteria. The main limitation of the classical AHP method is the inability to capture the ambiguities or inaccuracies associated with making decisions in a group. To address these deficiencies, the use of fuzzy theory has been proposed, allowing policy makers to more accurately assess the problem and integrate incomplete and uncountable information (Chen, 2000). The fuzzy analytic hierarchy process FAHP is a modification of the AHP method using the theory of fuzzy numbers in relation to a ninepoint comparison scale. Figure 1 presents a model view of the AHP / FAHP method, which consists of the following stages:

1. Determination of the main analysis purpose and creation of hierarchical structure of multi-criteria evaluation of the examined phenomenon (object assessment)
2. Selection of possible decision variants (alternatives), which will be assessed according to the adopted criteria.

3. Selection of criteria according to the fundamental principle of $7 \pm 2$ (in the case of more complex problems, it is also possible to specify sub-criteria).

4. Assessment of significance of criteria by pairwise comparison using the fundamental scale 1-9 for the analytic hierarchy process AHP or fuzzy scale 1-9 for the fuzzy analytic hierarchy process FAHP.

5. Creation of a normalized matrix on the basis of priority vectors and calculation of: the largest own size of the matrix $\lambda_{\max }$, the consistency index C.I (responsible for the lack of consequences of comparisons) and the consistency ratio C.R. (responsible for the coherence of comparisons in pairs)

6. Calculation of local priorities (according to points 4 and 5) for alternatives to each criterion.

7. Calculating the value of global priorities.

8. Optional performance of the sensitivity analysis, giving the answer as changes in the weights assigned to individual criteria, may affect the final result.

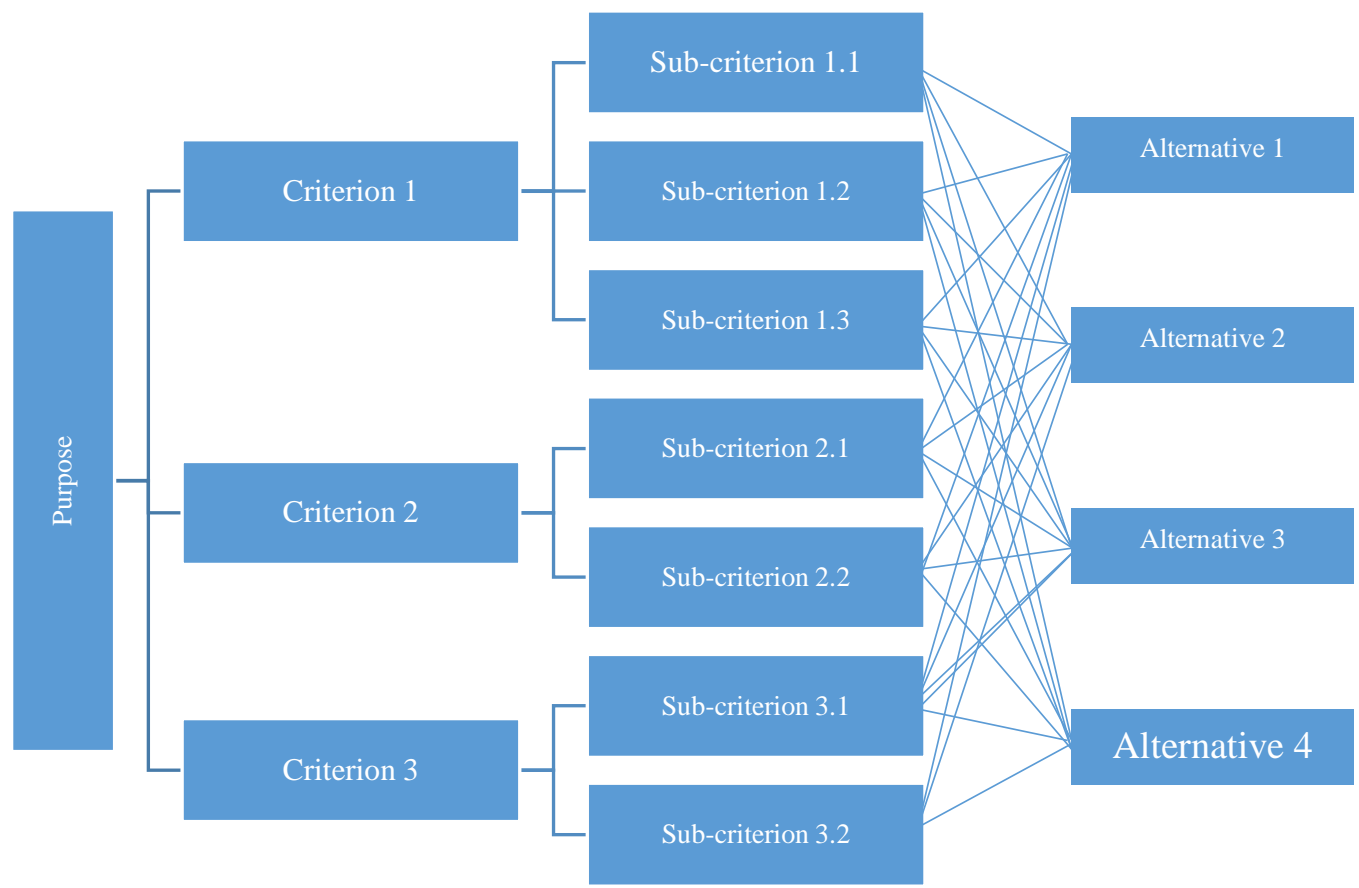

Figure 1. Decision hierarchy in AHP/FAHP method.

Source: Own elaboration based on (Saaty, 2002)

The application of the AHP / FAHP method is possible thanks to the fundamental Saati scale, used to assess pairs of individual criteria, sub-criteria and alternatives. Comparisons are made based on the expert knowledge and experience of the decision maker (or group of decision makers) in the field of the analyzed phenomena and objects. The main purpose of pairwise comparisons is to determine how many times the given item outweighs the other in relation to the criterion being assessed. Table 1 presents the main assumptions of the discussed scale in relation to the classical and fuzzy AHP method.

\begin{tabular}{|l|l|c|c|}
\hline \multicolumn{1}{|c|}{$\begin{array}{c}\text { Intensity of } \\
\text { Importance }\end{array}$} & Explanation & AHP & FAHP \\
\hline Equal importance & Element a and b contribute equally to the objective & $1=(1,1,1)$ \\
\hline $\begin{array}{l}\text { Moderate importance } \\
\text { of one over another }\end{array}$ & Slightly favor element a over b & $3=(2,3,4)$ \\
\hline Essential importance & Strongly favor element a over b & 3 & 5 \\
\hline $\begin{array}{l}\text { Demonstrated } \\
\text { importance }\end{array}$ & Element a is favored very strongly over b & $5=(4,5,6)$ \\
\hline $\begin{array}{l}\text { Absolute importance } \\
\text { importance }\end{array}$ & $\begin{array}{c}\text { The evidence favoring element a over b is of the highest possible order of } \\
7=(6,7,8)\end{array}$ & 9 \\
\hline $\begin{array}{l}\text { Intermediate values } \\
\text { between the two } \\
\text { adjacent judgments }\end{array}$ & $\begin{array}{l}\text { When compromise is needed. For example, } 4 \text { can be used for the intermediate } \\
\text { value between } 3 \text { and 5 }\end{array}$ & $\begin{array}{c}2,4,6,9,9) \\
4=(3,4,5) \\
6=(5,6,7) \\
8=(7,8,9)\end{array}$ \\
\hline
\end{tabular}

Table 1. The fundamental scale for pairwise comparisons.

Source: (Saaty, 2002), (Boutkhoum, Hanine, Agouti, \& Tikniouine, 2017) 
Regardless of the adopted assessment method (classical or fuzzy), the most important task of decision-makers is to determine the relationship between selected criteria by making a pairwise comparison. Expert evaluations form a square comparison matrix in pairs $(n \times n) A=\left[a_{i j}\right]$, which it performs $n(n-1) / 2$ of these comparisons. The consequence of this is a pairwise comparison of each criterion using the fundamental 1-9 scale and assigning the inverse of the evaluation for the second element.

\begin{tabular}{|c|c|c|c|c|}
\hline & $\begin{array}{c}\text { Criterion } \\
1\end{array}$ & $\begin{array}{c}\text { Criterion } \\
2\end{array}$ & $\begin{array}{c}\text { Criterion } \\
3\end{array}$ & $\begin{array}{c}\text { Criterion } \\
4\end{array}$ \\
\hline $\begin{array}{l}\text { Criterion } \\
1\end{array}$ & $1,1,1$ & $4,5,6$ & $\begin{array}{c}1 / 3,1 / 2 \\
1\end{array}$ & $\begin{array}{c}1 / 4,1 / 3, \\
1 / 2\end{array}$ \\
\hline $\begin{array}{l}\text { Criterion } \\
2\end{array}$ & $\begin{array}{c}1 / 6,1 / 5 \\
1 / 4\end{array}$ & $1,1,1$ & $\begin{array}{c}1 / 8,1 / 7 \\
1 / 6\end{array}$ & $\begin{array}{c}1 / 5,1 / 4 \\
1 / 3\end{array}$ \\
\hline $\begin{array}{l}\text { Criterion } \\
3\end{array}$ & $1,2,3$ & $6,7,8$ & $1,1,1$ & $\begin{array}{c}1 / 9,1 / 9 \\
1 / 9\end{array}$ \\
\hline $\begin{array}{l}\text { Criterion } \\
4\end{array}$ & $2,3,4$ & $3,4,5$ & $9,9,9$ & $1,1,1$ \\
\hline
\end{tabular}

Table 2. An example of pairwise comparison in the FAHP method.

Source: Own elaboration
In the case of expert group assessments, there is the problem of aggregating individual opinions to the final form, which is most often achieved by applying a geometric mean to all expert assessments. An example of a pairwise comparison matrix in the FAHP hierarchy method is shown in Table 2.

The next stages of using the AHP method are based on the calculation of a normalized matrix for selected criteria and the largest own size of the $\lambda_{\max }$ matrix. The author of the method proved that pairwise comparisons are all the more consistent, when the $\lambda_{\max }$ value is similar to the number of matrix elements $n$. On this basis, the calculation of the C.I consistency index was proposed, according to the formula:

and consistency ratio C.R.

$$
\text { C.I. }=\frac{\lambda_{\max }-n}{n-1}
$$

$$
\text { C.R. }=\frac{100 \% * C . I .}{R . I .}
$$

where R.I is a random consistency index, generated from several thousand matrices and proposed by the author in the form of

\begin{tabular}{|c|c|c|c|c|c|c|c|c|c|c|c|c|c|c|c|}
\hline n & 1 & 2 & 3 & 4 & 5 & 6 & 7 & 8 & 9 & 10 & 11 & 12 & 13 & 14 & 15 \\
\hline R.I. & 0 & 0 & 0,52 & $\mathbf{0 , 8 9}$ & 1,11 & 1,25 & 1,35 & 1,40 & 1,45 & 1,49 & 1,52 & 1,54 & 1,56 & 1,58 & 1,59 \\
\hline
\end{tabular}
table 3 .
It is assumed that the value of C.R. for matrix $(3 \times 3)$ and $(4 \times 4)$, should be adequate accordingly, less than or equal to $5 \%$ and $8 \%$, while for larger matrices it should not exceed $10 \%$ (C.R. $\leq 10 \%$ ). In that case consistency ratio C.R. is accepted, and the comparisons made are considered consistent. If the number of $10 \%$ is exceeded by the C.R. the criteria evaluation should be repeated in order to get rid of the incompatibility of comparisons in pairs. The next stage of the AHP analysis is the application of the same analytical technique to the sub-criteria (if identified), and next, to the proposed alternatives, which will allow determining the priorities within the adopted hierarchical structure.

The second multi-criteria method used in the discussed example is the TOPSIS method, which consists of determining the distance of the analyzed phenomenon or object (set with a finite number of elements) from the so-called, ideal and anti-ideal solution, resulting in a final, synthetic indicator that allows to create a ranking of the tested objectives (alternatives). The best element in the study is the one whose distance from the ideal solution is the smallest and at the same time has the largest distance from the anti-ideal solution. The use of the TOPSIS method includes the following steps:

1. Determination of weights for selected criteria; in the analyzed example the weight of the criteria will be determined by the FAHP method).

2. Creating a normalized data matrix according to the formula.

where $i=1,2, \ldots, m$ and $j=1,2, \ldots, n$

$$
z_{i j}=\frac{x_{i j}}{\sqrt{\sum_{i=1}^{m} x_{i j}^{2}}}
$$

3. Weight application according to the formula $v_{i j}=w_{j} \otimes z_{i j}$

4. Determination of the vector value of the ideal solution $\mathrm{A}^{+}$and anti-ideal $\mathrm{A}^{-}$(positive ideal solution, negative ideal solution)

$$
\begin{aligned}
a^{+}=\left(a_{1}^{+}, a_{2}^{+}, \ldots, a_{n}^{+}\right) & :=\left\{\left(\begin{array}{c}
\left.\operatorname{maxv}_{i j} \mid j \in J_{Q}\right),\left(\begin{array}{c}
\operatorname{minv}_{i j} \\
i=1, . ., m
\end{array} \mid j\right. \\
\left.\left.\in J_{c}\right)\right\}
\end{array}\right.\right. \\
a^{-}=\left(a_{1}^{-}, a_{2}^{-}, \ldots, a_{n}^{-}\right) & :=\left\{\left(\begin{array}{c}
\left.\operatorname{minv}_{i j} \mid j \in J_{Q}\right),\left(\begin{array}{c}
\operatorname{maxv}_{i j} \\
i=1, . ., m
\end{array} \mid j\right. \\
\left.\left.\in J_{c}\right)\right\}
\end{array}\right.\right.
\end{aligned}
$$

where $\mathrm{J}_{\mathrm{q}}$ is a beneficial criteria, and $\mathrm{J}_{\mathrm{c}}$ is a non-beneficial (cost) criteria.

5. Calculation of the Euclidean distance of the tested objects from the ideal and anti-ideal solution:

$$
S_{i}^{+}=\sqrt{\sum_{j=1}^{n}\left(v_{i j}-a_{j}^{+}\right)^{2}} \quad S_{i}^{-}=\sqrt{\sum_{j=1}^{n}\left(v_{i j}-a_{j}^{i}\right)^{2}}
$$

where $\mathrm{i}=1,2, \ldots, \mathrm{m}$ and $\mathrm{j}=1,2, \ldots, \mathrm{n}$

6. Calculation of the performance score $\mathrm{R}_{\mathrm{i}}$ for the examined objects, according to the formula:

$$
R_{i}=\frac{S_{i}^{-}}{S_{i}^{+}+S_{i}^{-}}
$$

The performance score $\mathrm{R}_{\mathrm{i}}$ of the highest value are the best solution (the best alternative) in the considered problem of linear ordering (ranking).

\section{Analysis of Sustainable Development of Poviats in the West Pomeranian Voivodeship In 2017}

The conducted characteristics of the FAHP and TOPSIS methods enables building a model for the analysis of socio-economic development of the poviats, based on the integration of the discussed methods and selected statistical data from the local data bank of the Statistical Office in West Pomeranian Voivodeship. The main assumptions of the model are:

1. Analysis and selection of criteria for assessing the level of poviat development are based on statistical data.

2. Application of the FAHP method is used to verify the adopted criteria and determine their weights.

3. Application of the TOPSIS method is used to analyze the level of sustainable development according to the adopted criteria and for building the poviats ranking in 2017.

The selection of criteria for assessing the level of social and economic development of the poviats was preceded by the analysis of statistical data collected in the local statistical database. The aim of the analysis was to take into account important factors determining the development of poviats, i.e. those that include demographic, economic, social, ecological and infrastructural issues. After the initial verification, based on the use of heuristic methods (method of transferring concepts, method of definition, incompetence method, analogy method), the list of factors was limited to 8 items and the following evaluation criteria were proposed:

- C1 - unemployment rate;

- $\mathrm{C} 2$ - birthrate per 1000 population;

- $\quad \mathrm{C} 3$ - income per capita;

- $\mathrm{C} 4$ - share of investment expenditures of poviats in total expenditure;

- C5 - number of applications for co-financing from EU funds in total after formal verification; 
- $\quad$ C6 - registered enterprises for 1000 population;

- $\quad$ C7 - percentage of the population using the sewage system;

- $\quad$ C8 - population per 1 library facility.

In the next stage of analysis, a fuzzy matrix of pairwise comparison was built, according to the fundamental scale for the FAHP method. Then, in order to the compliance of the criteria, the matrix was defuzzied, a normalized matrix was constructed and the largest own size of the $\lambda_{\max }$ matrix, which was 8.97 , was calculated. Next, the consistency index C.I $=0.139$ and the consistency ratio were calculated (for $\mathrm{n}=8$, R.I $=1.40$ ) and C.R $=0.099(9.9 \%)$. It is assumed that if the matrix $\mathrm{D}=[\mathrm{xij}]$ matches, the fuzzy matrix macierz $\widetilde{D}=\left[\tilde{x}_{i j}\right]$ also corresponds to this rule. On this basis, it can be assumed, in accordance with the assumptions of the FAHP method, that the consistency ratio may be accepted (is less than 10\%), which means that the comparisons made under the adopted comparison criteria are consistent.

The next step was to create a fuzzy normalized matrix (figure 5) and to calculate, using a geometric mean, weights for fuzzy numbers describing the individual criteria. Next, the defuzzification of fuzzy weights was carried out, the obtained results were normalized and the final results were obtained in the form of percentage weights determining the significance of selected criteria (table5)

\begin{tabular}{|c|c|c|c|c|c|c|c|c|c|c|c|c|c|c|c|c|c|c|c|c|c|c|c|c|}
\hline & \multicolumn{3}{|c|}{$\mathrm{C} 1$} & \multicolumn{3}{|c|}{$\mathrm{C} 2$} & \multicolumn{3}{|c|}{ C3 } & \multicolumn{3}{|c|}{$\mathrm{C} 4$} & \multicolumn{3}{|c|}{ C5 } & \multicolumn{3}{|c|}{ C6 } & \multicolumn{3}{|c|}{ C7 } & \multicolumn{3}{|c|}{$\mathrm{C} 8$} \\
\hline C1 & 0,27 & 0,22 & 0,15 & 0,31 & 0,29 & 0,25 & 0,20 & 0,27 & 0,31 & 0,11 & 0,14 & 0,15 & 0,07 & 0,10 & 0,11 & 0,20 & 0,19 & 0,18 & 0,10 & 0,15 & 0,18 & 0,17 & 0,20 & 0,21 \\
\hline $\mathrm{C} 2$ & 0,27 & 0,22 & 0,15 & 0,31 & 0,29 & 0,25 & 0,40 & 0,41 & 0,41 & 0,22 & 0,21 & 0,21 & 0,33 & 0,29 & 0,26 & 0,20 & 0,19 & 0,18 & 0,31 & 0,31 & 0,30 & 0,34 & 0,33 & 0,31 \\
\hline C3 & 0,09 & 0,11 & 0,15 & 0,08 & 0,10 & 0,12 & 0,20 & 0,14 & 0,10 & 0,22 & 0,21 & 0,21 & 0,20 & 0,19 & 0,19 & 0,20 & 0,19 & 0,18 & 0,31 & 0,31 & 0,30 & 0,25 & 0,26 & 0,26 \\
\hline $\mathrm{C} 4$ & 0,09 & 0,11 & 0,15 & 0,08 & 0,10 & 0,12 & 0,05 & 0,05 & 0,05 & 0,11 & 0,07 & 0,05 & 0,07 & 0,05 & 0,04 & 0,10 & 0,11 & 0,12 & 0,03 & 0,04 & 0,06 & 0,03 & 0,03 & 0,05 \\
\hline C5 & 0,09 & 0,11 & 0,15 & 0,04 & 0,05 & 0,05 & 0,04 & 0,03 & 0,03 & 0,11 & 0,07 & 0,05 & 0,07 & 0,05 & 0,04 & 0,02 & 0,02 & 0,03 & 0,03 & 0,03 & 0,03 & 0,03 & 0,03 & 0,05 \\
\hline C6 & 0,04 & 0,04 & 0,04 & 0,05 & 0,06 & 0,06 & 0,03 & 0,03 & 0,03 & 0,03 & 0,02 & 0,03 & 0,07 & 0,10 & 0,11 & 0,05 & 0,04 & 0,03 & 0,02 & 0,02 & 0,02 & 0,02 & 0,02 & 0,03 \\
\hline C7 & 0,09 & 0,11 & 0,15 & 0,06 & 0,07 & 0,08 & 0,04 & 0,03 & 0,03 & 0,11 & 0,14 & 0,15 & 0,13 & 0,14 & 0,15 & 0,15 & 0,15 & 0,15 & 0,10 & 0,08 & 0,06 & 0,08 & 0,07 & 0,05 \\
\hline C8 & 0,07 & 0,07 & 0,05 & 0,05 & 0,06 & 0,06 & 0,04 & 0,03 & 0,03 & 0,11 & 0,14 & 0,15 & 0,07 & 0,10 & 0,11 & 0,10 & 0,11 & 0,12 & 0,10 & 0,08 & 0,06 & 0,08 & 0,07 & 0,05 \\
\hline
\end{tabular}

Table 4. Normalized, fuzzy matrix of pairwise comparison for selected criteria.

Source: Own elaboration

The conducted research based on the fuzzy method of the analytic hierarchy process FAHP, allowed to establish consistent criteria determining the socio-economic development of the poviats and assigning them certain weights. In this place, it should be noted that the assessments based on pairwise comparisons, and hence the importance of individual criteria, will vary depending on the preferences, experience and subjective, arbitrary decisions of individual experts at a specific place and time. Nothing prevents the selection of criteria and their assessment from being carried out several times, also within different expert groups.

\begin{tabular}{|c|c|c|c|c|c|}
\hline Criterion & $\mathrm{l}$ & $\mathrm{m}$ & $\mathrm{u}$ & $\mathrm{COA}$ & Weights \\
\hline $\mathrm{C} 1$ & 0,16 & 0,18 & 0,18 & 0,18 & $18,89 \%$ \\
$\mathrm{C} 2$ & 0,29 & 0,27 & 0,25 & 0,27 & $28,94 \%$ \\
$\mathrm{C} 3$ & 0,18 & 0,17 & 0,18 & 0,18 & $18,96 \%$ \\
$\mathrm{C} 4$ & 0,06 & 0,06 & 0,07 & 0,07 & $7,04 \%$ \\
$\mathrm{C} 5$ & 0,04 & 0,04 & 0,05 & 0,04 & $4,75 \%$ \\
$\mathrm{C} 6$ & 0,04 & 0,04 & 0,04 & 0,04 & $3,84 \%$ \\
$\mathrm{C} 7$ & 0,09 & 0,09 & 0,09 & 0,09 & $9,66 \%$ \\
$\mathrm{C} 8$ & 0,07 & 0,08 & 0,07 & 0,07 & $7,91 \%$ \\
\hline
\end{tabular}

\section{\begin{tabular}{|l|l|l|l|}
\hline & Sum & 0,929 & $100 \%$ \\
\hline
\end{tabular} lower, m-medium, u-upper), defuzzyfication method (COA center of area) and normalized weights for selected criteria. Source: Own elaboration}

Separate criteria and their weights allow to proceed to the next stage of the analysis, based on the use of the TOPIS method for linear ordering, i.e. the ranking of poviats in the West Pomeranian Voivodeship in 2017, in the context of adopted criteria. Figure 7 contains statistical data corresponding to selected criteria for poviats of West Pomeranian Voivodship, being the basis for expert analysis.

An important element in the TOPSIS analysis is to understand the nature of the assessment, which can take on the characteristics of benefcial or non-beneficial (cost) criteria. In the analyzed example, criterion $\mathrm{C} 1$ - the unemployment rate and $\mathrm{C} 8$ population per 1 library facility, are cost criteria (the desired value should be kept to a minimum); the remaining $\mathrm{C} 2-\mathrm{C} 7$ criteria are beneficial for which the desired values are going to the maximum. According to the TOPSIS methodology, a normalized weighted matrix was created (weights were obtained using the FAHP method, table 7), and then vectors for ideal and anti-ideal solutions were calculated.

\begin{tabular}{|l|c|c|c|c|c|c|c|c|}
\hline \multicolumn{1}{|c|}{ Poviat } & C1 & C2 & C3 & C4 & C5 & C6 & C7 & C8 \\
\hline bialogardzki & 19,40 & $-1,39$ & 1225,46 & 7,30 & 659,00 & 101,10 & 99,69 & 4804,10 \\
\hline choszczeński & 17,80 & $-1,77$ & 1098,67 & 10,35 & 539,00 & 83,57 & 99,52 & 1686,41 \\
\hline drawski & 16,90 & $-1,40$ & 1253,35 & 8,43 & 564,00 & 102,60 & 99,58 & 2138,11 \\
\hline goleniowski & 6,10 & 0,81 & 1018,75 & 13,94 & 786,00 & 110,47 & 99,76 & 3058,04 \\
\hline gryficki & 11,60 & $-1,26$ & 1351,07 & 6,76 & 658,00 & 126,60 & 99,52 & 4348,93 \\
\hline gryfiński & 11,70 & $-0,65$ & 903,89 & 8,56 & 552,00 & 103,28 & 99,72 & 3190,42 \\
\hline kamieński & 16,60 & $-1,36$ & 1156,98 & 13,74 & 458,00 & 150,80 & 99,82 & 2055,70 \\
\hline kolobrzeski & 4,70 & $-0,94$ & 1279,22 & 14,94 & 598,00 & 161,47 & 99,98 & 3618,00 \\
\hline koszaliński & 13,60 & 0,41 & 1326,43 & 15,16 & 792,00 & 113,01 & 99,52 & 1299,39 \\
\hline myśliborski & 8,90 & $-1,99$ & 1104,56 & 12,46 & 427,00 & 102,90 & 99,70 & 2380,29 \\
\hline policki & 5,00 & 3,61 & 1185,43 & 23,74 & 747,00 & 142,81 & 99,97 & 7833,30 \\
\hline
\end{tabular}


Hab. Prof. US Adam Stecyk

\begin{tabular}{|l|c|c|c|c|c|c|c|c|}
\hline pyrzycki & 13,00 & $-1,88$ & 1092,11 & 6,91 & 546,00 & 93,90 & 99,62 & 1812,41 \\
\hline sławieński & 15,50 & $-0,32$ & 1003,56 & 13,23 & 550,00 & 104,08 & 99,81 & 2468,00 \\
\hline stargardzki & 8,90 & $-0,33$ & 967,81 & 11,30 & 872,00 & 102,30 & 99,77 & 4141,07 \\
\hline szczecinecki & 16,50 & $-1,14$ & 1217,25 & 8,77 & 761,00 & 101,71 & 99,70 & 2235,20 \\
\hline świdwiński & 16,00 & $-1,53$ & 1419,59 & 10,07 & 662,00 & 94,43 & 99,83 & 2382,15 \\
\hline walecki & 9,70 & $-1,47$ & 948,03 & 11,75 & 456,00 & 104,45 & 99,84 & 4133,69 \\
\hline lobeski & 21,20 & $-0,75$ & 1152,29 & 11,75 & 477,00 & 87,14 & 99,63 & 4675,13 \\
\hline Koszalin & 5,40 & $-0,32$ & 5150,81 & 15,77 & 549,00 & 167,96 & 99,83 & 9788,18 \\
\hline Szczecin & 3,10 & $-1,65$ & 5333,31 & 13,58 & 1963,00 & 172,75 & 99,93 & 11218,97 \\
\hline Świnoujście & 5,00 & $-3,56$ & 8082,01 & 14,24 & 207,00 & 151,91 & 99,94 & 6838,67 \\
\hline
\end{tabular}

Table 6. Statistical data corresponding to selected criteria for poviats of the West Pomeranian Voivodship.

Source: Own elaboration based on local database https://bdl.stat.gov.pl/BDL/start

On the basis of the obtained results, a performance score $\mathrm{R}_{\mathrm{i}}$ was calculated, enabling the ranking of poviats of the West Pomeranian Voivodship according to specific criteria C1-C8. Table 8 contains a list of poviats, ordered by the score (descending sorting). Detailed analysis of the results obtained, exceeds the scope of this study (for this purpose a specific expert sensitivity analysis of individual criteria should be carried out), nevertheless, it is possible to group poviats according to the synthetic social and economic development factor and a subjective reference point based on expert knowledge in the area of regional development. The group achieving a satisfactory level of development may include poviats that achieved the $\mathrm{R}_{\mathrm{i}}>0.4$, i.e. the poviat of Police, Goleniów and the city of Koszalin. The group of poviats for which the ranking belongs to the range from 0.3 to 0.4 may be defined as a set with a sufficient level of socio-economic development. The remaining poviats can be included in the group with insufficient level of development and requiring special attention in the future.

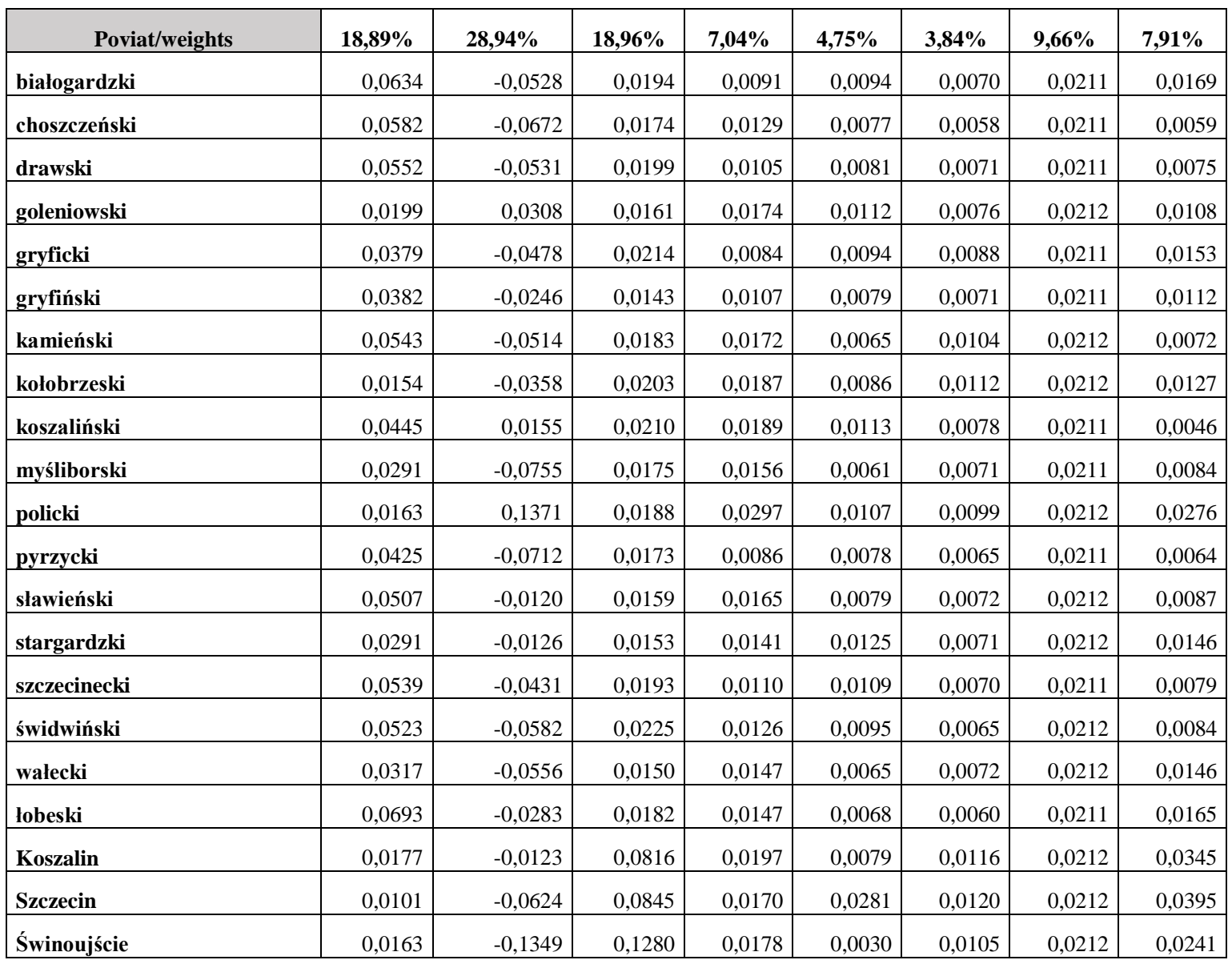

Table 7. A normalized weighted matrix for the poviats of the West Pomeranian Voivodeship. Source: Own elaboration

\section{Summary}

The conducted research is a starting point for further, in-depth analyzes and scientific discussions. However, it is already possible to make a preliminary summary of both the methodological and substantive areas in the context of sustainable development in West Pomeranian. The most important applications include:
1. The key stage of the analysis is the proper selection of criteria determining the level of assessment of social and

economic development of poviats in the West Pomeranian Voivodeship. From this point of view, the proposed C1-C8 factors are a subjectively selected set that can be subjected to any modifications, depending on the purpose of the analysis. What's more, the concept proposed is of a general nature. It seems 
reasonable to specify the purpose of the analysis (eg within a more restricted area, such as municipal management, ecology, demography, public finances, etc.) and the selection of appropriate characteristics.

\begin{tabular}{|c|c|c|c|c|}
\hline Lp. & Poviat & S+ & S- & Ranking \\
\hline 1 & policki & 0,251 & 0,326 & 0,566 \\
\hline 2 & goleniowski & 0,330 & 0,240 & 0,421 \\
\hline 3 & Koszalin & 0,333 & 0,227 & 0,405 \\
\hline 4 & koszaliński & 0,342 & 0,212 & 0,383 \\
\hline 5 & Szczecin & 0,376 & 0,214 & 0,363 \\
\hline 6 & stargardzki & 0,365 & 0,205 & 0,360 \\
\hline 7 & kołobrzeski & 0,381 & 0,204 & 0,349 \\
\hline 8 & sławieński & 0,367 & 0,189 & 0,339 \\
\hline 9 & gryfiński & 0,377 & 0,191 & 0,336 \\
\hline 10 & Świnoujście & 0,438 & 0,212 & 0,326 \\
\hline 11 & gryficki & 0,393 & 0,179 & 0,313 \\
\hline 12 & walecki & 0,401 & 0,181 & 0,310 \\
\hline 13 & lobeski & 0,381 & 0,164 & 0,301 \\
\hline 14 & szczecinecki & 0,392 & 0,167 & 0,299 \\
\hline 15 & myśliborski & 0,418 & 0,175 & 0,295 \\
\hline 16 & kamieński & 0,399 & 0,163 & 0,290 \\
\hline 17 & drawski & 0,401 & 0,161 & 0,286 \\
\hline 18 & świdwiński & 0,403 & 0,161 & 0,286 \\
\hline 19 & pyrzycki & 0,416 & 0,164 & 0,282 \\
\hline 20 & białogardzki & 0,400 & 0,154 & 0,279 \\
\hline 21 & choszczeński & 0,414 & 0,151 & 0,268 \\
\hline
\end{tabular}

Table 8. Ranking of poviats of West Pomeranian

Voivodeship in 2017 according to selected criteria. Source: Own elaboration

2. In the adopted fuzzy analytic hierarchy process FAHP, the main role is played by the knowledge and experience of experts who evaluate the criteria based on reversible pairwise comparisons. From this point of view, both the purpose of the analysis and the competences of individual experts are important for the final results of the study.

3. In terms of methods, the proposed methodology, based on a combination of two methods: FAHP and TOPSIS, deserves attention. The question arises about the possibility of modifying the computational model both in the area of choice of methods (eg parallel analysis based on other models and comparison of results), and in the method itself (eg resignation of fuzzy numbers in AHP hierarchy analysis, or vice versa, using fuzzy numbers in TOPSIS analysis, etc.)

Summing up, it should be noted that regardless of the substantive (eg choice of criteria) and methodical problems (method selection), the use of multi-criteria methods will be increasingly applicable to decision-makers responsible for both local and central politics, as well as managers in commercial enterprises. Each subsequent empirical study and new computational models are a step forward in the search for, even if not perfect, then at least, the search that best describes the reality of the decision solutions, which are the basis for sustainable development.

\section{References}

i. Bana e Costa, C., \& Vansnick, F. (1999). Sur la quantification des jugements de valeur: $L$ 'approche Macbeth, Cahiiers du LAMSADE. Paris: Universite Paris Dauphine. ii. Banayoun, R., Roy, B., \& Sussman, N. (1966). Manual de Reference du Programme Electre, Note de Synthese et Formation 25. Direction Scientifique SEMA.

iii. Bewszko, T. (2004). Wielokryterialna analiza zasilania $w$ energie odbiorcy komunalnobytowego. Rzeszów: Politechnika Rzeszowska.

iv. Boutkhoum, O., Hanine, M., Agouti, T., \& Tikniouine, A. (2017). A decision-maiking approach based on fuzzy AHPTOPSIS metodology for selecting appropriate cloud solution to manage big data. International Journal of System Assurance Engineering and Management.

v. Charnes, A., Cooper, W., \& Rhodes, E. (1978). Measuring the efficiency of decision making units. European Journal of the Operational Research No 2, pp. 63-85.

vi. Chen, C. T. (2000). Extensions of the TOPSIS for group decisionmaking under fuzzy environment. Fuzzy Sets Systems 114(1), strony 1-9.

vii. Diech, W., Korbicz, J., Rutkowski, L., \& Tadeusiewicz, R. (2000). Sieci neuronowe. Akademicka Oficyna.

viii. Edwards, W., \& Barron, F. (1994). SMARTS and SMARTER: improved Simple methods for mulitiattribute measurement. Organizational behavior and human decison process, p. 60.

ix. Jahanshahloo, G., Hosseinzadeh Lotfi, F. i Izadikhah, M. (1999). Extension of the TOPSIS method for decisionmaking problems with fuzzy data. Applied mathematics and Computation 185, strony 1544-1551.

x. Roy, B. (1990). Wielokryterialne wspomaganie decyzji. Warszawa: Wydawnictwo Naukowo-Techniczne.

xi. Saaty, R. (2002). Decision Making in Complex Environments: The Analytic Network Process (ANP) for Dependence and Feedback; a manual for the ANP Software SuperDecisions. Creative Decisions Foundation,.

xii. Triantaphyllou, E. (2000). Multi-Criteria Decision Making Methods. In: Multi-criteria Decision Making Methods: A Comparative Study. Boston: Springer.

xiii. Trzaskalik, T. (2014). Wielokryterialne wspomaganie decyzji. Metody i zastosowania. Warszawa: PWE

xiv. Witkowska, D. (1996). Wprowadzenie do badań operacyjnych. Łódź: Wydawnictwo Poloitechniki Łódzkiej. 